\title{
JPEB
}

Jurnal Penelitian Ekonomi dan Bisnis, 1 (2), 2016, Hal : 100 - 118

\section{KOMPARASI TINGKAT KESEHATAN DUAL BANGKING SISTEM ANTARA DIVISI KONVENSIONAL DAN SYARIAH DI INDONESIA}

\author{
Rohimah $^{1 *}$ dan Rifki Khoirudin ${ }^{2}$ \\ 1,2 Jurusan Ekonomi Pembangunan, Fakultas Ekonomi dan Bisnis, Universitas Ahmad Dahlan \\ Jalan Kapas No. 9, Semaki, Yogyakarta, 55166, Indonesia \\ *Corresponding Author: ep21rohimah@gmail.com
}

Diterima: Februari 2016; Direvisi: Juni 2016; Dipublikasikan: September 2016

\begin{abstract}
This research aims to know the level of health ratio of conventional banks and islamic banks in Indonesia that have Dual Banking System. The sample of this research is 25 conventional bank and 24 islamic bank. This type of research is quantitative research. This research was analyzed using RGEC approach. The variables that used in this research consisted of Risk Profile factor assessed with NPL ratio and LDR of Earning factors assessed by ROA and BOPO ratio, and Capital factor was assessed through CAR ratio. Hypothesis testing in this study using independent sample t-test. From the calculation of the health level of banks, conventional banks are healthier than islamic banks. While the results obtained by using independent test sample t-test in this study showed that the ratio of NPL and CAR there is no significant difference. While the ratio of LDR, ROA, and BOPO there are significant differences.
\end{abstract}

Keywords : Risk Profil; Earning; Capital

\section{ABSTRAK}

Penelitian ini bertujuan untuk mengetahui tingkat perbandingan kesehatan bank konvensional dan bank syariah di Indonesia yang memiliki Dual Banking Sistem. Sampel dalam penelitian ini adalah 25 bank konvensional dan 24 bank syariah. Jenis penelitian ini adalah penelitian kuantitatif. Penelitian ini dianalisis menggunakan metode pendekatan RGEC.Variabel yang digunakan dalam penelitian ini terdiri dari faktor Risk Profil dinilai dengan rasio NPL dan LDR faktor Earning dinilai dengan rasio ROA dan BOPO, dan faktor Capital dinilai melalui rasio CAR. Pengujian hipotesis dalam penelitian ini menggunakan independen sample t-test. Dari hasil perhitungan tingkat kesehatan perbankan, bank konvensional lebih sehat dibandingkan bank syariah. Sedangkan dari hasil yang diperoleh dengan menggunakan uji independen sample t-test dalam penelitian ini menunjukan bahwa pada rasio NPL dan CAR tidak terdapat perbedaan yang signifikan. Sedangkan pada rasio LDR, ROA, dan BOPO terdapat perbedaan yang signifikan.

Kata Kunci: Risk Profil; Earning; Capital 


\section{PENDAHULUAN}

Pada era globalisasi saat ini, bank merupakan bagian dari sistem keuangan dan sistem pembayaran dunia. Keberadaan sektor perbankan memiliki peran penting dalam kehidupan masyarakat sehari-hari, sebagian besar hampir melibatkan jasa-jasa perbankan. Bagi msyarakat yang hidup di negara-negara maju seperti negara-negara di Eropa, Amerika dan Jepang, bank sudah bukan merupakan barang yang asing. Bank sudah menjadi mitra bagi masyarakat dalam rangka memenuhi semua kebutuhan keuangan mereka. Bank dijadikan sebagai tempat untuk melakukan berbagai transaksi yang berhubungan dengan keuangan seperti, tempat mengamankan uang, melakukan investasi, pengiriman uang, serta melakukan berbagai pembayaran dan melakukan penagihan.

Hal ini dikarenakan pengenalan dunia perbankan secara utuh terhadap masyarakat sangatlah minim. Sehingga tidak mengherankan keruntuhan dunia perbankan pun tidak terlepas dari kurang pahamnya pengelola perbankan di tanah air dalam memenuhi dunia perbankan secara utuh. Bank secara sederhana dapat diartikan sebagai lembaga keungan yang kegiatan usahanya adalah menghimpun dana dari masyarakat dan menyalurkan kembali dana tersebut ke masyarakat seta memberikan jasa-jasa bank lainnya (Kasmir, 2014).

Pada umumnya bank yang sehat adalah bank yang dapat menjalankan fungsifungsinya dengan baik, yaitu dapat menjaga dan memelihara kepercayaan masyarakat dan menjalankan fungsi intermediasi dalam membantu kelancaran lalu lintas pembayaran, dapat digunakan oleh pemerintah dalam melaksanakan kebijakan moneter, serta sebagai sarana untuk mencapai stabilitas sistem keuangan yang menjalankan usahanya berdasarkan prinsip kepercayaan.

Oleh sebab itu agar dapat menjalankan fungsinya dengan baik, bank di tuntut untuk berada dalam kondisi yang sehat berdasarkan prinsip kehati-hatian. Penilaian kesehatan bank sangat penting disebabkan karena bank mengelola dana masyarakat yang dipercayakan kepada bank. Masyarakat pemilik dana dapat saja menarik dana yang dimilikinya setiap saat dan bank harus sanggup mengembalikan dana yang dipakainya jika ingin tetap dipercaya oleh masyarakat. Standar untuk melakukan penilaian tingkat kesehatan bank telah ditentukan oleh pemerintah melalui Bank Indonesia. Bank-bank di Indonesia harus membuat laporan yang bersifat rutin mengenai seluruh aktivitasnya dalam suatu periode tertentu. Laporan tersebut akan dipelajari dan dianalisis, sehingga dapat diketahui kondisi suatu bank. Salah satu tolak ukur yang bisa dijadikan sebagai standar dalam engukuran kesehatan suatu bank yaitu sistem penilaian yang ditetapkan oleh Bank Indonesia. Penilaian tersebut menggunakan rasio keuangan yakni NPL, LDR, ROA, BOPO, dan CAR.

\section{Tabel 1. Indikator Utama Bank Umum}

\begin{tabular}{lccc}
\hline \multicolumn{1}{c}{ Indikator Utama } & Des 2011 & Des 2010 & Des 2011 \\
\hline Total Aset (T Rp) & $2.534,11$ & $3.008,85$ & $3.652,83$ \\
DPK (T Rp) & $1.973,04$ & $2.338,82$ & $2.784,91$ \\
Kredit (T Rp) & $1.437,93$ & $1.765,84$ & $2.200,09$ \\
CAR \% & 17,42 & 17,18 & 16,05 \\
NPL gross (\%) & 3,31 & 2,56 & 2,17 \\
NPL Net (\%) & 0,33 & 0,26 & 0,39 \\
ROA (\%) & 2,60 & 2,86 & 3,03 \\
BOPO (\%) & 86,63 & 86,14 & 85,42 \\
LDR (\%) & 72,88 & 75,50 & 79,00 \\
\hline
\end{tabular}


Rohimah Dan Rifki Khoirudin: Komparasi Tingkat Kesehatan Dual Bangking Sistem Antara Divisi Konvensional dan Syariah Di Indonesia

Pada tahun 2011 penyaluran kredit dan penghimpunan DPK meningkat dengan baik. kredit perbankan tumbuh 24,59\% menjadi Rp2.200,09 Triliun atau lebih tinggi dibandingkan pertumbuhan tahun 2010 sebesar 22,08\%, pertumbuhan kredit tersebut tepatap didominasi oleh kredit produktif yakni Kredit Modal Kerja (KMK) dan Kredit Investasi (KI). Membaiknya kondisi perekonomian mendorong meningkatnya permintaan kredit dari masyarakat dan penawaran kredit dari perbankan. Pertumbuhan kredit tersebut masih bisa ditingkatkan lagi di masa depan. Hal ini tercermin dari LDR tahun 2011 yang masih berada pada kisaran $79,00 \%$. Sementara itu pada Bank Umum Syariah penghimpunan DPK dan penyaluran pembiayaan meningkat cukup baik selama 2011. DPK meningkat Rp39,38 Triliun $(51,80 \%)$ dan pembiayaan tumbuh $\mathrm{Rp} 34,47$ Triliun $(50,56 \%)$ atau lebih tinggi dibandingkan tahun 2010 yang hanya tumbuh 45,43\%.

Tabel 2. Indikator Utama Bank Umum Syariah dan Unit Syariah

\begin{tabular}{lccc}
\hline \multicolumn{1}{c}{ Indikator Utama } & Des 2011 & Des 2010 & Des 2011 \\
\hline Total Aset (T Rp) & 66,09 & 97,52 & 145,47 \\
DPK (T Rp) & 52,27 & 76,03 & 115,41 \\
Pembiayaan (T Rp) & 46,88 & 68,18 & 102,65 \\
CAR \% & 10,77 & 16,25 & 16,63 \\
NPFs gross (\%) & 4,01 & 3,02 & 2,52 \\
NPFs Net (\%) & 1,84 & 1,6 & 1,34 \\
ROA (\%) & 1,48 & 1,67 & 1,79 \\
BOPO (\%) & 86,63 & 86,14 & 85,42 \\
LDR (\%) & 89,70 & 89,67 & 88,94 \\
\hline
\end{tabular}

Pembiayaan perbankan syariah setiap tahun mengalami peningkatan, hal ini didominasi oleh pembiayaan konsumtif dan modal kerja yang masing-masing memiliki pangsa pasar sebesar $41,94 \%$ dan 40,62\%. Sedangkan dari sisi pertumbuhan, kredit kredit konsumsi meningkat dengan pesat yakni sebesar $87,93 \%$ dibanding tahun sebelumnya. Peningkatan kredit konsumtif tersebut terjadi karena maraknya masyarakat yang melakukan Gadai Emas.

Dari sisi pendapatan, pendapatan operasional perbankan syariah (BUS dan UUS) tercatat sebesar Rp14,95 Triliun tahun 2011 meningkat cukup signifikan sebesar 49,40\% (yoy). Hal tersebut terutama didorong oleh pertumbuhan aset produktif yang cukup signifikan tercermin dari pendapatan dari penyaluran dana yang tercatat sebesar Rp10,70 Triliun atau meningkat $44,30 \%$ (yoy). Sumber pendapatan lain yang mendukung pertumbuhan pendapatan operasional adalah pendapatan dari jasa layanan. ROA pada tahun 2010 sebesar 1,67\% meningkat menjadi $1,79 \%$ pada tahun 2011 disebabkan oleh peningkatan laba yang tumbuh sebesar 40,33\% menjadi Rp1,48 Triliun. Sementara dari sisi tingkat pengembalian investasi, peningkatan laba tersebut tidak diikuti dengan peningkatan ROE yang tercatat menurun dari $17,63 \%$ menjadi $15,72 \%$. Kondisi itu disebabkan oleh adanya tambahan modal disetor pada beberapa Bank Umum Syariah.

Dalam proses penegakan hukum, Bank Indonesia hanya memiliki kewenangan yang menyangkut pengenaan sanksi administratif kepada pihak Bank, sedangkan untuk pengenaan sanksi atas pelanggaran yang mengandung unsur pidana diperlukan proses penyidikan lebih lanjut yang merupakan kewenangan pihak penegak hukum, yaitu Kepolisian dan Kejaksaan.

Dalam rangka memberikan perlindungan kepada konsumen perbankan, Bank Indonesia melakukan pengawasan untuk menyelesaikan permasalahan pada bank, untuk mengembalikan kepercayaan pada nasabah, serta mencegah terulangnya permasalahan yang sama, salah satunya dengan cara meningkatkan tingkat kesehtan bank menggunakan pendekatan pengawasan berdasarkan risiko. Pengawasan berdasarkan risiko telah diterapkan oleh Bank 
Indonesia sejak tahun 2003. Berdasarkan penerapan pada risiko, Bank Indonesia menerapkan sistem penilaian tingkat kesehatan bank dengan menggunakan metode CAMELS yang terdiri dari faktor Permodalan (Capital), Kualitas Aset (Asset Quality), Manajemen (Management), Rentabilitas (Earnings), Likuiditas (Liquidity), dan Sensitivitas terhadap Risiko Pasar (Sensitivity to Market Risk). Namun Bank Indonesia perlu melakukan penyempurnaan dalam pengawasan bank dengan mengeluarkan peraturan baru tentang penilaian tingkat kesehatan bank yaitu melalui Surat Keputusan Direksi BI No. 13/1/PBI/2011 tahun 2011, yaitu penilaian tingkat kesehatan bank dengan menggunakan metode pendekatan risiko yakni Risk-based Bank Rating. Metode Risk-based Bank Rating atau RBBR merupakan metode yang terdiri dari empat faktor penilaian yakni Risk Profile, Good Corporate Governance (GCG), Earning, dan Capital.

Dengan adanya gejolak keuangan global yang terjadi, penting bagi perusahaan perbankan untuk mengidentifikasi apakah kondisi perusahaan perbankan tersebut dalam keadaan sehat atau tidak sehat, karena jika terlambat teridentifikasi maka biaya yang harus dikeluarkan oleh bank akan jauh lebIh mahal sebagai usaha untuk menyelesaikan kesulitan keuangan yang dialami oleh perusahaan perbankan tersebut. Suatu bank dapat dikatakan sehat apabila mampu menjalankan fungsi-fungsinya dengan baik, dapat melakukan operasional secara normal serta dapat memenuhi semua kewajiban sesuai dengan peraturan perbankan yang berlaku. Dengan mengetahui tingkat kesehatan bank maka seluruh pihak yang terkait dapat mengukur sejauh mana pengelolaan bank telah sesuai dengan asas pengelolaan bank yang sehat dan ketentuan yang berlaku di Indonesia, selain itu dengan mengetahui tingkat kesehatan bank dapat bermanfaat untuk meningkatkan efisiensi kinerja bank dalam kegiatan operasionalnya sehingga dapat mengoptimalkan keuntungan dan kemungkinan kebangkrutan dapat dihindari.

Pada peraturan yang dikeluarkan oleh Bank Indonesia pada tanggal 25 0ktober 2011 melalui Surat Keputusan Direksi BI No. 13/1/PBI/2011 tahun 2011. Peraturan baru ini merupakan penyempurnaan dari metode CAMELS yang sebelumnya digunakan. Metode baru yang ditetapkan oleh Bank Indonesia merupakan metode dengan pendekatan risiko yakni Risk-based Bank Rating. Metode Risk-based Bank Rating atau RBBR merupakan metode yang terdiri dari empat faktor penilaian yakni Risk Profile, Good Corporate Governance (GCG), Earning, dan Capital. Surat Edaran BI No 13/24/DPNP menjelaskan bahwa profil risiko merupakan penilaian terhadap risiko inheren dan kualitas penerapan manajemen risiko yang mencakup 8 jenis risiko yaitu, risiko pasar, risiko kredit, risiko likuiditas, risiko operasional, risiko hukum, risiko stratejik, risiko kepatuhan dan risiko reputasi. Faktor kedua yang menjadi dasar penilaian adalah Good Corporate Governance (GCG). Penilaian terhadap faktor GCG mencakup kedalam tiga aspek utama yakni, governance structure, governance process, dan governance output.

Rentabilitas (earning) merupakan salah satu faktor yang digunakan dalam pengukuran tingkat kesehatan bank. Penilaian terhadap faktor ini mencakup atas kinerja rentabilitas, sumber-sumber rentabilitas, kesinambungan (suistainability) rentabilitas, dan manajemen rentabilitas. Surat Edaran BI No 13/24/DPNP menerangkan kinerja rentabilitas dapat dinilai dengan menggunakan rasio keuangan yakni Return on Asset (ROA) dan Biaya Operasional/Pendapatan Operasional (BOPO). Faktor permodalan (Capital) dapat dinilai dengan menggunakan rasio keuangan yakni Capital Adequecy Ratio (CAR).

Di Indonesia terdapat dua jenis perbankan, yaitu bank konvensional dan bank syariah. Bank konvensional yaitu bank yang pada kegiatan usahanya berdasarkan pada pembayaran bunga. Sedangkan Bank Syariah adalah bank yang menjalankan kegiatan usahanya berdasarkan prinsip syariah dan menurut jenisnya terdiri atas Bank Umum Syariah dan Bank Pembiayaan Rakyat Syariah. 
Rohimah Dan Rifki Khoirudin: Komparasi Tingkat Kesehatan Dual Bangking Sistem Antara Divisi Konvensional dan Syariah Di Indonesia

Dengan adanya dua jenis bank tersebut maka peneliti tertarik untuk menggunakan metode Risk Based Bank Rating. Penelitian ini bertujuan untuk mengetahui perbandingan tingkat kesehatan bank konvensional dan bank syariah di Indonesia. Sedangkan variabel independen yang digunakan dalam penelitian ini terdiri dari aspek Risk Profile dinilai melalui NPL (Non Performing Loan) dan LDR (Loans to Deposit Ratio), aspek Earnigs yang penilaiannya dilakukan dengan ROA (Return On Asset) dan BOPO (Biaya Operasional/Pendapatan Operasional), faktor Capital dengan menggunakan indikator CAR (Capital Adequacy Ratio).

\section{TINJAUAN PUSTAKA \\ Penelitian Terdahulu}

Widyaningrum (2014) melakukan penelitian terhadap bank yang terdaftar di Bursa Efek Indonesia dalam sub sektor perbankan 2012 yang diberi judul "analisis tingkat kesehatan bank dengan menggunakan metode Risk-Based Bank Rating (RBBR)". Dalam penelitian ini terdapat empat faktor yaitu risk profile dengan menggunakan rasio NIM, Good Corporate Governance, earning dinilai melalui faktor ROA, dan capital menggunakan rasio CAR. Jenis penelitian yang digunakan dalam penelitian ini adalah penelitian deskriptif dengan menggunakan pendekatan kuantitatif. Hasil penelitian yang diperoleh menunjukan bahwa dalam raiso ROA masih terdapat bank yang tidak sehat dengan nilai ROA 1,25\%, penilaian NIM dan CAR menunjukan keseluruhan bank berada dalam kondisi sehat.

Hidayatika (2016) dalam penelitiannya "analisi perbedaan tingkat kesehatan bank konvensional dengan menggunakan metode RGEC". Penelitian ini menggunakan metode RGEC untuk menganalisis tingkat kesehatan bank yang terdiri ari 41 populasi dan 12 sampel. Sampel dalam peneitian ini adalah bank yang termasuk dalam kategori bank yang memiliki modal inti kurang dari 1 triliun. Alat analisi yang digunakan adalah uji statistik one-way ANOVA untuk menentukan perbedaan beberapa bank konvensional. Hasil yang diperoleh dari penelitian ini kedua belas bank yang menjadi sampel berada dalam keadaan sehat.

\section{Pengertian Bank}

Bank adalah lembaga keuangan yang kegiatan usahanya adalah menghimpun dana dari masyarakat dan menyaurkan kembali dana tersebut ke mesyarakat serta memberikan jasa-jasa bank lainnya (Kasmir, 2014). Menurut Undang-Undang Nomor 10 Tahun 1998 dan perubahan Undang-Undang Nomor 7 Tahun 1992 tentang perbankan disebutkan bahwa definisi bank adalah badan usaha yang menghimpun dana dari masyarakat dalam bentuk simpanan dan menyalurkan kepada masyarakat dalam bentuk kredit atau bentuk-bentuk lainnya dalam rangka meningkatkan taraf hidup masyarakat banyak. Bank juga merupakan merupakan lembaga keuangan yang usaha pokoknya memberikan kredit dan jasa-jasa dalam lalu lintas pembayaran dan peredaran uang (Sinangun, 1993). Dari berbagai penjelasan di atas dapat disimpulkan bahwa usaha perbankan meliputi tiga kegiatan, yaitu menghimpun dana, menyalurkan dana, dan memberikan jasa bank lainnya.

\section{Pengertian Bank Konvensional}

Bank yang dalam kegiatan operasionalnya menetapkan bunga sebagai harga, untuk produk simpanan sepert giro, tabungan maupun deposito. Demikian pula harga untuk produk jaminannya (kredit) juga ditentukan berdasarkan tingkat suku bunga tertentu. Metode bunga sudah ada terlebih dahulu, menjadi kebiasaan dan telah dipakai secara meluas dibandingkan dengan metode bagi hasil. 


\section{Pengertian Bank Syariah}

Menurut Undang-Undang No. 10 tahun 1998 bank syariah adalah bank yang melaksanakan kegiatan usahanya berdasarkan prinsip syariah yang dalam kegiatannya memberikan jasa dalam lalu lintas pembayaran.prinsip syariah menurut Pasal 1 ayat 13 Undang-undang No.10 tahun 1998 tentang perbankan adalah aturan perjanjian berdasarkan hukum islam antara bank dan pihak lain untuk penyimpanan dana dan atau pembiayaan kegiatan usaha, atau kegiatan lainnya yang dinyatakan sesuai dengan syariah, antara lain pembiayaan berdasarkan prinsip bagi hasil (mudharabah), pembiayaan berdasarkan prinsip penyertaan modal (musharakah), prinsip jual beli barang dengan keuntungan (murabahah), atau pembiayaan barang modal berdasarkan prinsip sewa murni tanpa pilihan (ijarah), atau dengan adanya pilihan pemindahan kepemilikan atas barang yang disewa dari pihak oleh pihak lain (ijarah wa iqtina).

\section{Perbedaan Bank Konvensional dan Bank Syariah} berikut ini:

Berikut ini merupakan perbedaan antara kedua bank yang dijelaskan dalam tabel

Tabel 3. Perbedaan Antara Bank Konvensional dan Bank Syariah

\begin{tabular}{|c|c|c|}
\hline Perbedaan & Bank Konvensional & Bank Syariah \\
\hline Kepemilikan Modal & $\begin{array}{l}\text { Pemilik dana } \\
\text { memperoleh imbalan } \\
\text { berupa bungan simpanan } \\
\text { yang tinggi. }\end{array}$ & $\begin{array}{l}\text { Islam memandang harta yang } \\
\text { dimiliki oleh manusia adalah titipan } \\
\text { Allah SWT sehingga cara } \\
\text { memperoleh, mengelola, dan } \\
\text { memanfaatkannya harus sesuai } \\
\text { ajaran islam. }\end{array}$ \\
\hline Orientasi & Keuntungan semata & $\begin{array}{l}\text { Keuntungan dan kemakmuran dan } \\
\text { kebahagiaan dunia akhirat. }\end{array}$ \\
\hline Partisipasi Nasabah & $\begin{array}{l}\text { Tidak adanya ikatan } \\
\text { emosional yang kuat } \\
\text { anata Pemegang Saham, } \\
\text { Pengelola Bank dan } \\
\text { Nasabah karena masing- } \\
\text { masing pihak } \\
\text { mempunyai keinginan } \\
\text { yang bertolak belakang. }\end{array}$ & $\begin{array}{l}\text { Adanya kesamaan ikatan emosional } \\
\text { yang kuat didasarkan prinsip } \\
\text { keadilan, prinsip kesederajatan dan } \\
\text { prinsip ketentraman antara } \\
\text { Pemegang Saham, Pengelola Bank } \\
\text { dan Nasabah atas jalannya uasaha } \\
\text { bank syariah }\end{array}$ \\
\hline Keuntungan & Bunga & Bagi hasil \\
\hline $\begin{array}{l}\text { Hubungan Nasabah } \\
\text { dan Bank }\end{array}$ & Kreditur dan debitur & Kemitraan \\
\hline $\begin{array}{l}\text { Keberadaan dewan } \\
\text { pengawas }\end{array}$ & Tidak ada & Ada \\
\hline
\end{tabular}


Rohimah Dan Rifki Khoirudin: Komparasi Tingkat Kesehatan Dual Bangking Sistem Antara Divisi Konvensional dan Syariah Di Indonesia

Dari tabel di atas jelas ada perbedaan yang sangat jelas antara bank konvensional dan bank syariah, kita dapat melihat dari partisipasi nasabah. Pada nasabah bank syariah memiliki rasa atau ikatan emosional yang didasarkan pada prinsip keadilan atas keberlangsungannya usaha bank, namun pada nasabah bank konvensional hanya mementingkan diri sendiri tanpa memperdulikan aspek keadilan.

\section{Penilaian Tingkat Kesehatan Bank}

Menurut Surat Edaran Bank Indonesia Nomor 13/1/PBI/2011 tentang Penilaian Tingkat Kesehatan Bank Umum, Bank wajib melakukan penilaian Tingkat Kesehatan Bank dengan menggunakan pendekatan berdasarkan Risiko (Risk-based Bank Rating). Penilaian Tingkat Kesehatan Bank dilakukan terhadap Bank secara individual maupun konsolidasi, dengan cakupan penilaian meliputi faktor-faktor sebagai berikut: Profil Risiko (risk profile), Good Corporate Governance (GCG), Rentabilitas (earnings); dan Permodalan (capital) untuk menghasilkan Peringkat Komposit Tingkat Kesehatan Bank. Pada prinsipnya tingkat kesehatan, pengelolaan Bank, dan kelangsungan usaha Bank merupakan tanggung jawab sepenuhnya dari manajemen Bank.

Oleh karena itu, Bank wajib memelihara dan memperbaiki tingkat kesehatannya dengan menerapkan prinsip kehati-hatian dan Manajemen Risiko dalam melaksanakan kegiatan usahanya termasuk melakukan penilaian sendiri (self assessment) secara berkala terhadap tingkat kesehatannya dan mengambil langkah-langkah perbaikan secara efektif. Di lain pihak, Bank Indonesia mengevaluasi, menilai Tingkat Kesehatan Bank, dan melakukan tindakan pengawasan yang diperlukan dalam rangka menjaga stabilitas sistem keuangan.

Untuk menilai suatu kesehatan bank dapat dilihat dari beberapa segi. Penilaian ini bertujuan untuk menentukan apakah bank tersebut dalam kondisi sehat atau tidak sehat, sehingga Bank Indonesia sebagai pengawas dan pembina bank-bank dapat memberikan arahan atau petunjuk bagaimana bank tersebut harus dijalankan atau bahkan dihentikan kegiatan operasinya. Ukuran untuk melakukan penilaian kesehatan bank telah dibuat dan ditentukan oleh Bank Indonesia. Sedangkan bank-bank diharuskan untuk membuat laporan baik bersifat rutin ataupun secara berkala mengenai seluruh aktivitasnya dalam suatu periode tertentu.

Menurut Peratuan Bank Indonesia Nomor 13/1/PBI/2011 tentang Penilaian Tingkat Kesehatan Bank Umum, Bank wajib melakukan penilaian Tingkat Kesehatan Bank dengan menggunakan pendekatan berdasarkan Risiko (Risk-based Bank Rating). Penilaian Tingkat Kesehatan Bank secara individual mencakup penilaian terhadap faktor-faktor berikut: faktor Riks Profil (Profil Risiko), faktor Good Corporate Gvernance (GCG), faktor Earning (Rentabilitas), dan faktor Capital (Permodalan).

\section{Penilaian Profil Risiko}

Penilaian faktor Profil Risiko merupakan penilaian terhadap Risiko inheren dan kualitas penerapan Manajemen Risiko dalam aktivitas operasional Bank. Risiko yang wajib dinilai terdiri atas 8 (delapan) jenis Risiko yaitu Risiko Kredit, Risiko Pasar, Risiko Operasional, Risiko Likuiditas, Risiko Hukum, Risiko Stratejik, Risiko Kepatuhan, dan Risiko Reputasi

1. Penilaian Risiko Inheren

Penilaian Risiko inheren merupakan penilaian atas Risiko yang melekat pada kegiatan bisnis Bank, baik yang dapat dikuantifikasikan maupun yang tidak, yang berpotensi mempengaruhi posisi keuangan Bank. Karakteristik Risiko inheren Bank ditentukan oleh faktor internal maupun eksternal, antara lain strategi bisnis, karakteristik bisnis, kompleksitas produk dan aktivitas Bank, industri dimana Bank melakukan 
kegiatan usaha, serta kondisi makro ekonomi. Berikut ini adalah beberapa indikator minimum yang wajib dijadikan acuan oleh bank dalam menilai resiko inhern.

2. Risiko Kredit

Merupakan risiko akibat kegagalan debitur dan/atau pihak lain dalam memenuhi kewajiban kepada bank. Risiko kredit biasanya terdapat pada seluruh aktivitas bank yang kinerjanya bergantung pada pihak lawan (counterparty), penerbit (issuer), atau kinerja peminjam dana (borrower). Risiko kredit juga dapat diakibatkan oleh terkonsentrasinya penyediaan dana pada debitur, wilayah geografis, produk, jenis pembiayaan, atau lapangan usaha tertentu.

3. Risiko Pasar

Merupakan risiko pada posisi neraca dan rekening administratif termasuk transaksi derivatif, akibat perubahan dan kondidi pasar, termasuk risiko perubahan harga option. Risiko pasar meliputi risiko suku bunga, risiko nilai tukar, risiko ekuitas, dan risiko komoditas.

4. Risiko likuiditas

Merupakan risiko yang diakibatkan oleh ketidakmampuan bank dalam memenuhi kewajiban yang jatuh tempo dari sumber pendanaan arus kas, dan/atau dari aset likuid berkualitas tinggi yang dapat diagunkan, tanpa mengganggu aktivitas dan kondisi keuangan bank. Risiko likuiditas ini juga dapat disebabkan oleh ketidakmampuan bank melikuidasi aset tanpa terkena diskon yang material kerena tidak adanya pasar aktif atau adanya gangguan pasar yang parah.

5. Risiko Operasional

Merupakan resiko akibat ketidakcukupan dan/atau tidak berfungsinya proses internal, kesalahan manusia, kegagalan sistem, atau adanya kejadian eksternal yang mempengaruhi operasional bank. Sumber risiko operasional dapat disebabkan antara lain oleh sumber daya manusia, proses, sistem, dan kejadian eksternal.

6. Risiko Hukum

Merupakan risiko yang timbul akibat tuntutan hukum dan/atau kelemahan aspek yuridis. Risiko ini juga dapat timbul karena ketiadaan peraturan perundang-undangan yang mendasari atau kelemahan perikatan, seperti tidak dipenuhinya syarat sahnya kontrak atau agunan yang tidak memadai.

7. Risiko stratejik

Merupakan risiko akibat ketidaktepatan bank dalam mengambil keputusan dan/atau melaksanakan suatu keputusan stratejik serta kegagalan dalam mengantisipasi perubahan lingkungan bisnis. Dalam risiko stratejik sumber risikoya dapat ditimbulkan dari kelemahan dalam proses formulasi strategi dan ketidaktepatan dalam implementasi strategi, dan kegagalan mengantisipasi perubahan lingkungan bisnis.

8. Risiko Kepatuhan

Merupakan risiko yang timbul akibat bank tidak memenuhi dan/atau tidak melaksanakan peraturan perundangan undangan dan ketentuan yang berlaku. Sumber risio kepatuhan timbul kerena kurangnya pemahaman atau kesadaran hukum terhadap ketentuan maupun standar bisnis yang berlaku umum.

9. Risiko Reputasi

Merupakan ririko akibat menurunnya tingkat kepercayaan stakeholder yang bersumber dari persepsi negatif terhadap bank.

\section{Penilaian Good Corporate Governance (GCG)}

Penilaian faktor GCG merupakan penilaian terhadap kualitas manajemen bank atas pelaksanaan 5 (lima) prinsip GCG yaitu transparansi, akuntabilitas, pertanggungjawaban, independensi dan kewajaran. Prinsip-prinsip GCG dan fokus penilaian terhadap pelaksanaan 
Rohimah Dan Rifki Khoirudin: Komparasi Tingkat Kesehatan Dual Bangking Sistem Antara Divisi Konvensional dan Syariah Di Indonesia

prinsip-prinsip GCG berpedoman pada ketentuan Bank Indonesia mengenai pelaksanaan GCG bagi bank umum dengan memperhatikan karakteristik dan kompleksitas usaha bank. Penetapan peringkat faktor GCG dilakukan berdasarkan analisis atas: (i) pelaksanaan prinsipprinsip GCG, (ii) kecukupan tata kelola (governance) atas struktur, proses, dan hasil penerapan GCG pada bank, dan (iii) informasi lain yang terkait dengan GCG bank yang didasarkan pada data dan informasi yang relevan. Cakupan penerapan prinsip-prinsip GCG Bank Indonesia paling kurang harus diwujudkan dalam: (1) Pelaksanan tugas dan tanggung jawab Dewan Komisaris, (2) Pelaksanaan tugas dan tanggung jawab Direksi, (3) Kelengkapan dan pelaksanaan tugas Komite (4) Penanganan benturan kepentingan, (5) Penerapan fungsi kepatuhan (6) Penerapan fungsi audit intern, (7) Penerapan fungsi audit ekstern, (8) Penerapan manajemen risiko termasuk sistem pengendalian intern, (9) Penyediaan dana kepada pihak terkait (related party) dan penyedian adan besar (large exposures), (10) Transparansi kondisi keuangan dan non keuangan bank, laporan pelaksanaan GCG dan pelaporan internal, dan (11) Rencana strategis bank.

\section{Penilaian Earnings (Rentabilitas)}

Penilaian faktor rentabilitas meliputi evaluasi terhadap kinerja rentabilitas, sumbersumber rentabilitas, kesinambungan (sustainability) rentabilitas, dan manajemen rentabilitas. Penetapan faktor rentabilitas dilakukan berdasarkan analisis yang komprehensif dan terstruktur terhadap parameter/indikator rentabilitas dengan memperhatikan signifikansi masing-masing indikator serta permasalahan lain yang mempengaruhi rentabilitas bank. Berdasarkan lampiran 17 dalam Kodifikasi Penilaian Kesehatan Bank tentang matriks perhitungan/analisis faktor rentabilitas (Earnings) dapat menggunakan beberapa rasio keuangan diantaranya rasio Net Operating Margin, (NOM), Return on Assets (ROA), Rasio Efisiensi Operasional (REO), dan Return on Equity (ROE), Biaya Operasional/Pendapatan Operasional (BOPO).

\section{Penilaian Capital (Permodalan)}

Penilaian atas faktor permodalan meliputi evaluasi terhadap kecukupan permodalan dan kecukupan pengelolaan permodalan. Dalam melakukan perhitungan permodalan, bank wajib mengacu pada ketentuan Bank Indonesia yang mengatur mengenai Kewajiban Penyediaan Modal Minimum (KPMM) bagi bank umum. Selain itu, dalam melakukan penilaian kecukupan permodalan, bank juga harus mengaitkan kecukupan modal dengan profil risiko bank. Semakin tinggi risiko bank, semakin besar modal yang harus disediakan untuk mengantisipasi risiko tersebut.

Parameter/indikator dalam menilai Permodalan meliputi:

1. Kecukupan modal Bank Penilaian kecukupan modal Bank perlu dilakukan secara komprehensif, minimal mencakup: (1) tingkat, trend, dan komposisi modal Bank, (2) Rasio KPMM dengan memperhitungkan Risiko Kredit, Risiko Pasar, dan Risiko Operasional, dan (3) Kecukupan modal Bank dikaitkan dengan Profil Risiko.

2. Pengelolaan Permodalan Bank Analisis terhadap pengelolaan Permodalan Bank meliputi manajemen Permodalan dan kemampuan akses Permodalan.

Keempat faktor tersebut memang merupakan faktor yang menentukan kondisi suatu bank. Apabila suatu bank mengalami permasalahan pada salah satu aspek maka bank tersebut akan mengalami kesulitan keuangan. Apalagi jika suatu bank mengalami permasalahan yang menyangkut lebih dari satu aspek yang merupakan kategori penilaian tingkat kesehatan dapat terjadi kemungkinan kebangkrutan bank tersebut. 


\section{Kerangka Pemikiran}

Dalam menilai tingkat kesehatan bank baik konvensional maupun syariah dapat dilihat dari laporan keuangan yang di publikasikan oleh bank bersangkutan. Dari laporan keuangan tersebut dapat kita hitung menggunakan alat ukur tingkat kesehatan bank yang di atur oleh Bank Indonesia dengan cara menggukan metode RGEC. Penelitian ini tidak hanya menghitung tingkat kesehatan bank yang memilii dual banking sistem namun juga membandingkan tingkat kesehatan antara bank antara divisi konvensional dan divisi syariah, untuk membandingkan pada perbankan yang memiliki dual banking sistem dilakukan uji beda.

Berikut ini merupakan gambaran kerangka pemikiran yang di jelaskan dengan gambar sebagai berikut:

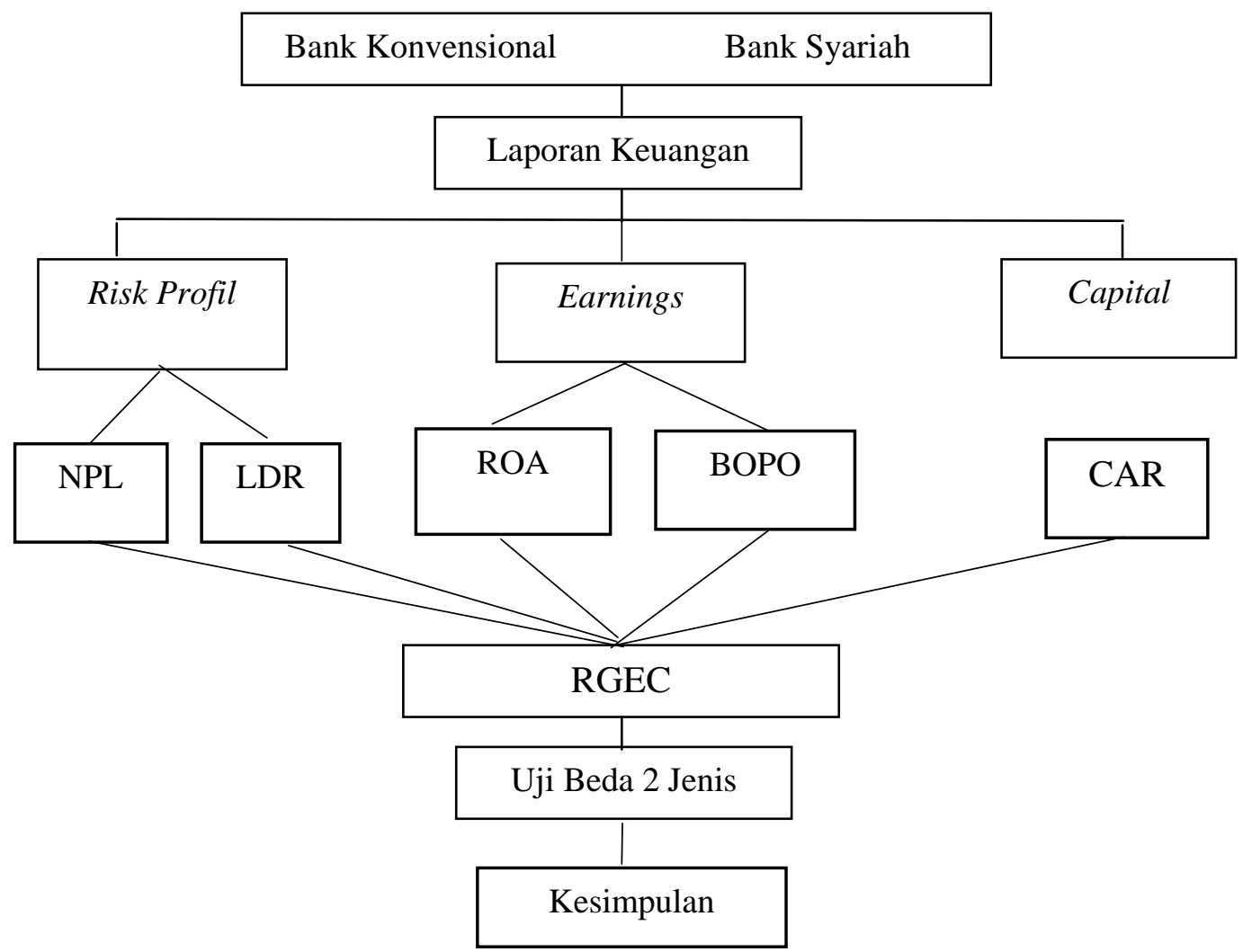

Gambar 1. Kerangka Pemikiran

\section{Hipotesis}

Berdasarkan uraian diatas, maka hipotesis penelitian adalah sebagai berikut :

1. Diduga bahwa rasio keuangan bank konvensional dan bank syariah menggunakan metode RGEC berada pada predikat sehat.

2. Diguga bahwa terdapat perbedaan tingkat kesehatan masing-masing rasio keuangan yang signifikan antara bank konvensional dan bank syariah.

\section{METODE PENELITIAN}

Data yang digunakan dalam penelitian ini adalah data kuantitatif dengan menggunakan data sekunder yang diambil dari laporan tahunan masing-masing bank. Data sekunder merupakan data yang diperoleh dari laporan keuangan bank yang dipublikasikan oleh bank masing-masing. Laporan keuangan yang digunakan adalah laporan keuangan neraca, laporan keuangan laba rugi, dan laporan keuangan tahunan bank. Penelitian ini dilakukan dalam ruang 
Rohimah Dan Rifki Khoirudin: Komparasi Tingkat Kesehatan Dual Bangking Sistem Antara Divisi Konvensional dan Syariah Di Indonesia

lingkup bank yang memiliki dual sistem yakni bank yang bergerak secara konvensional dan bank yang bergerak secara syariah.

Sasaran penelitian ini adalah untuk mengetahui masing-masing aspek Risk Profile dinilai melalui NPL (Non Performing Loan) dan LDR (Loans to Deposit Ratio), aspek Earnigs yang penilaiannya dilakukan dengan ROA (Return On Asset) dan BOPO (Biaya Operasional/Pendapatan Operasional), faktor Capital dengan menggunakan indikator CAR (Capital Adequacy Ratio), pada tingkat kesehatan bank konvensional dan bank syariah di Indonesia.

Dalam penelitian ini juga menggunakan analisis analisis tingkat kesehatan bank dengan menggunkan pendekatan risiko (Risk-based Bank Rating/RBBR). Berikut adalah langkahlangkah yang akan digunakan dalam penelitian ini diantaranya:

\section{Aspek Risiko Kredit}

Aspek yang pertama adalah mengukur kualitas manajemen resiko kredit, kredit dalam hal ini adalah kredit bermasalah yang diukur melalui NPL. Rasio ini dapat dirumuskan sebagai berikut:

$$
\text { NPL }=\frac{\text { Kredit Bermasalah }}{\text { Total Kredit }} \times 100 \%
$$

Tabel 4. Kriteria penetapan peringkat NPL

\begin{tabular}{ccc}
\hline No. & Hasil Rasio & Kriteria \\
\hline 1 & $<5 \%$ & Sehat \\
2 & $>5 \%$ & Tidak sehat \\
\hline
\end{tabular}

\section{Aspek Likuiditas}

Analisis rasio likuiditas ini bertujuan untuk mengukur kemampuan bank dalam memenuhi kewajiban jangka pendeknya yang diukur melalui LDR. Rasio ini dirumuskan sebagai berikut:

$$
\text { LDR }=\frac{\text { Total Kredit }}{\text { Total Dana Pihak Ketiga }} \times 100 \%
$$

\section{Tabel 5. Kriteria penetapan peringkat LDR}

\begin{tabular}{ccc}
\hline No. & Hasil Rasio & Kriteria \\
\hline 1 & $<100 \%$ & Sehat \\
2 & $>100 \%$ & Tidak sehat \\
\hline
\end{tabular}

\section{Aspek Rentabilitas}

Merupakan aspek yang digunakan untuk mengukur kemampuan dalam meningkatkan keuntungan dengan jumlah modal yang dimiliki yang diukur melalui Return on asset (ROA). Kemampuan ini dilakukan dalam satu periode. Rasio ini dirumuskan sebagai berikut:

$$
\text { ROA }=\frac{\text { Laba Sebelum Pajak }}{\text { Rata-rata Total Asset }} \text { X 100\% }
$$


Tabel 6. Kriteria Penetapan Tingkat ROA

\begin{tabular}{ccc}
\hline No. & Hasil Rasio & Kriteria \\
\hline 1 & $>0,5 \%$ & Sehat \\
2 & $<0,5 \%$ & Tidak sehat \\
\hline & BOPO $=\frac{\text { Biaya Operasional }}{\text { Pendapatan Operasional }} \times 100 \%$
\end{tabular}

Tabel 7. Kriteria Penetapan Tingkat BOPO

\begin{tabular}{ccc}
\hline No. & Hasil Rasio & Kriteria \\
\hline 1 & $<94 \%$ & Sehat \\
2 & $>94 \%$ & Tidak sehat \\
\hline
\end{tabular}

\section{Aspek Capital}

Permodalan (capital) suatu bank. Dalam aspek ini yang dinilai adalah permodalan yang dimiliki oleh bank yang didasarkan kepada kewajiban penyediaan modal minimum bank. Rasio ini dirumuskan sebagai berikut:

$$
\text { CAR }=\frac{\text { Modal Bank }}{\text { Total ATMR }} \times 100 \%
$$

\section{Tabel 8. Kriteria Penetapan Tingkat CAR}

\begin{tabular}{ccc}
\hline No. & Hasil Rasio & Kriteria \\
\hline 1 & $>8 \%$ & Sehat \\
2 & $<8 \%$ & Tidak sehat \\
\hline
\end{tabular}

Melakukan analisis dengan pengolahan data untuk membandingkan tingkat kesehatan masing-masing rasio keuangan antara Bank Konvensional dengan Bank Syariah di Indonesia dengan menggunakan teknik statistik yang berupa uji beda dua rata-rata (independent sample t-test). Tujuannya untuk menentukan menerima atau menolak hipotesis yang telah dibuat sebagai berikut:

Jika $\mathrm{F}$ hitung dengan Equal variance assumed (diasumsi kedua varians sama) memiliki nilai sig. > 0.05 maka dinyatakan bahwa kedua varian sama. Bila kedua varians sama, maka sebaiknya menggunakan dasar Equal variance assumed (diasumsi kedua varian sama) untuk thitung. Jika t hitung sig. < 0.05, dikatakan masing-masing rasio keuangan Bank Konvensional dengan Bank Syariah di Indonesia terdapat perbedaan yang signifikan, sebaliknya jika t hitung sig > 0.05 dinyatakan masing-masing rasio keuangan Bank Konvensional dengan Bank Syariah di Indonesia tidak terdapat perbedaan yang signifikan.

Jika $\mathrm{F}$ hitung dengan Equal variance assumed (diasumsi kedua varians sama) memiliki nilai sig . $<0.05$, maka dinyatakan bahwa kedua varians berbeda. Bila kedua varians berbeda, maka untuk membandingkan kedua Bank dengan test sebaiknya menggunakan dasar Equal variance not assumed (diasumsi kedua varian tidak sama) untuk $\mathrm{t}$ hitung. Jika t hitung dengan Equal variance not assumed memiliki sig. > 0.05, dapat dikatakan bahwa masingmasing rasio keuangan Bank Konvensional dengan Bank Syariah Indonesia tidak terdapat perbedaan yang signifikan, namun jika sig. $<0.05$, dapat dinyatakan bahwa masing-masing 
Rohimah Dan Rifki Khoirudin: Komparasi Tingkat Kesehatan Dual Bangking Sistem Antara Divisi Konvensional dan Syariah Di Indonesia

rasio keuangan Bank Konvensional dengan Bank Syariah di Indonesia terdapat perbedaan yang signifikan. (Djarwanto, PS; Subagyo, P. 2002).

\section{HASIL DAN PEMBAHASAN}

Bank Konvensional

Pada bank konvensional tingkat kesehatan bank dapat dihitung dengan menggunakan metode RGEC. Analisis RGEC dapat dihitung melalui profil risiko dengan menggunakan aspek risiko kredit yang dihitung melalui rasio NPL (Non Performing Loan), aspek risiko likuiditas yang dinilai melaui rasio LDR (Loan to Deposit Ratio), aspek earnings yang penilaiannya dilakukan dengan rasio ROA (Return On Asset) dan BOPO (Biaya Operasional/Pendapatan Operasional), serta aspek Capital yang dihitung melaui rasio CAR (Capital Adequacy Ratio). Perhitungan tingkat kesehatan bank berdasarkan Surat Edaran BI No. 13/24/DPNP/2011 maka perhitungan dari masing-masing rasio adalah sebagai berikut:

Tabel 9. Hasil Perhitungan Masing-masing Rasio Pada Bank Konvensional (Dalam Satuan Persen)

\begin{tabular}{|c|c|c|c|c|c|c|c|}
\hline \multirow[b]{2}{*}{ No } & \multirow[b]{2}{*}{ Nama Bank } & \multirow[b]{2}{*}{ Tahun } & \multicolumn{5}{|c|}{ Kriteria Kesehatan Bank } \\
\hline & & & $\begin{array}{l}\text { NPL } \\
<5 \%\end{array}$ & $\begin{array}{c}\text { LDR } \\
<100 \%\end{array}$ & $\begin{array}{c}\text { ROA } \\
>0,5 \%\end{array}$ & $\begin{array}{l}\text { BOPO } \\
<94 \%\end{array}$ & $\begin{array}{l}\text { CAR } \\
>8 \%\end{array}$ \\
\hline \multirow[t]{5}{*}{1.} & BNI & 2011 & $3,6 \%$ & $67,7 \%$ & $2,5 \%$ & $65,8 \%$ & $17,6 \%$ \\
\hline & & 2012 & $2,8 \%$ & $77,9 \%$ & $2,7 \%$ & $61,4 \%$ & $16,7 \%$ \\
\hline & & 2013 & $2,2 \%$ & $85,9 \%$ & $2,9 \%$ & $55,1 \%$ & $15,1 \%$ \\
\hline & & 2014 & $2.0 \%$ & $92,5 \%$ & $3,2 \%$ & $58,2 \%$ & $16,2 \%$ \\
\hline & & 2015 & $2,0 \%$ & $70,8 \%$ & $2,1 \%$ & $59,7 \%$ & $19,5 \%$ \\
\hline \multirow[t]{5}{*}{2.} & BRI & 2011 & $2,3 \%$ & $74,3 \%$ & $3,9 \%$ & $57,1 \%$ & $14,9 \%$ \\
\hline & & 2012 & $1,8 \%$ & $77,9 \%$ & $4,7 \%$ & $56,2 \%$ & $16,9 \%$ \\
\hline & & 2013 & $1,6 \%$ & $86,1 \%$ & $4,5 \%$ & $55,6 \%$ & $16,9 \%$ \\
\hline & & 2014 & $1,7 \%$ & $79,6 \%$ & $3,8 \%$ & $59,6 \%$ & $18,3 \%$ \\
\hline & & 2015 & $2,0 \%$ & $84,4 \%$ & $3,7 \%$ & $59,7 \%$ & $20,5 \%$ \\
\hline \multirow[t]{5}{*}{3.} & Bank Bukopin & 2011 & $2,8 \%$ & $85,1 \%$ & $1,6 \%$ & $79,7 \%$ & $12,7 \%$ \\
\hline & & 2012 & $2,7 \%$ & $84,4 \%$ & $1,6 \%$ & $78,8 \%$ & $16,3 \%$ \\
\hline & & 2013 & $2,4 \%$ & $86,8 \%$ & $1,7 \%$ & $84,1 \%$ & $15,1 \%$ \\
\hline & & 2014 & $2,8 \%$ & $84,5 \%$ & $1,2 \%$ & $86,3 \%$ & $14,2 \%$ \\
\hline & & 2015 & $2,8 \%$ & $84,5 \%$ & $1,3 \%$ & $83,8 \%$ & $13,5 \%$ \\
\hline \multirow[t]{5}{*}{4.} & Bank Mega & 2011 & $0,9 \%$ & $63,9 \%$ & $1,9 \%$ & $81,6 \%$ & $12,8 \%$ \\
\hline & & 2012 & $2,1 \%$ & $53,7 \%$ & $2,4 \%$ & $76,5 \%$ & $17,6 \%$ \\
\hline & & 2013 & $2,8 \%$ & $57,6 \%$ & $1 \%$ & $89,5 \%$ & $16,1 \%$ \\
\hline & & 2014 & $2,1 \%$ & $65,9 \%$ & $1,0 \%$ & $91,8 \%$ & $16,3 \%$ \\
\hline & & 2015 & $2,8 \%$ & $65,1 \%$ & $1,8 \%$ & $85,9 \%$ & $23,9 \%$ \\
\hline \multirow[t]{5}{*}{5.} & Bank Panin & 2011 & $3,5 \%$ & $80,5 \%$ & $2,2 \%$ & $70,2 \%$ & $17,4 \%$ \\
\hline & & 2012 & $2,7 \%$ & $89,3 \%$ & $2,0 \%$ & $71,4 \%$ & $14,6 \%$ \\
\hline & & 2013 & $2,1 \%$ & $85,7 \%$ & $1,9 \%$ & $73,9 \%$ & $15,3 \%$ \\
\hline & & 2014 & $2,0 \%$ & $88,8 \%$ & $2,0 \%$ & $76,9 \%$ & $15,7 \%$ \\
\hline & & 2015 & $2,4 \%$ & $91,8 \%$ & $1,3 \%$ & $78,9 \%$ & $19,9 \%$ \\
\hline
\end{tabular}

Dari data tebel di atas, NPL pada Bank Negara Indonesia tahun 2012 mengalami penurunan dibanding tahun sebelumnya, yaitu dari 3,6\% ditahun 2011 menjadi 2,8\% ditahun 2012. Hal itu disebabkan oleh penurunan jumlah kredit bermasalah ditahun 2012 tercatat sebesar Rp5,6 triliun menurun Rp5,9 triliun tahun 2011. Secara keseluruhan tingkat kesehatan Bank Negara Indonesia tahun 2011-2015 berada pada kondisi sehat. Pada tingkat likuiditas yang diukur dengan rasio LDR Bank Rakyat Indonesia pada tahun 2011-2012 berada dalam 
kondisi sehat karena masih berada di bawah batas maksimal yang ditentukan oleh Bank Indonesia sebesar $100 \%$. Secara keseluruhan masing-masing rasio yang terdapat pada bank konvensional baik itu BNI, BRI, Bank Bukopin, Bank Mega, dan Panin berada dalam kriteria sehat.

\section{Bank Syariah}

Seperti halnya tingkat kesehatan pada bank konvensional yang dihitung menggunakan metode RGEC yang dapat dihitung melalui masing-masing rasio pada aspek profil risiko, profil likuiditas, earning, dan capital, bank syariah pun menggunakan metode yang sama dalam melakukan perhitungan tingkat kesehatan bank. Maka hasil perhitungan dari masingmasing rasio pada bank syariah dapat dilihat pada tabel di bawah ini:

\section{Tabel 10. Hasil Perhitungan Masing-masing Rasio Pada Bank Syariah (dalam satuan persen)}

\begin{tabular}{|c|c|c|c|c|c|c|c|}
\hline \multirow[b]{2}{*}{ No } & \multirow[b]{2}{*}{ Nama Bank } & \multirow[b]{2}{*}{ Tahun } & \multicolumn{5}{|c|}{ Kriteria Kesehatan Bank } \\
\hline & & & $\begin{array}{l}\text { NPL } \\
<5 \%\end{array}$ & $\begin{array}{c}\text { LDR } \\
<100 \%\end{array}$ & $\begin{array}{c}\text { ROA } \\
>0,5 \%\end{array}$ & $\begin{array}{l}\text { BOPO } \\
<94 \%\end{array}$ & $\begin{array}{l}\text { CAR } \\
>8 \%\end{array}$ \\
\hline \multirow[t]{5}{*}{1.} & BNI Syariah & 2011 & $3,6 \%$ & $78,6 \%$ & $1,0 \%$ & $87,8 \%$ & $20,6 \%$ \\
\hline & & 2012 & $2,6 \%$ & $84,9 \%$ & $1,3 \%$ & $94,6 \%$ & $19,1 \%$ \\
\hline & & 2013 & $1,9 \%$ & $99,4 \%$ & $1,2 \%$ & $87,6 \%$ & $16,2 \%$ \\
\hline & & 2014 & $1,8 \%$ & $92,6 \%$ & $1,1 \%$ & $85,2 \%$ & $18,4 \%$ \\
\hline & & 2015 & $2,5 \%$ & $91,9 \%$ & $1,3 \%$ & $80,0 \%$ & $15,5 \%$ \\
\hline \multirow[t]{5}{*}{2.} & BRI Syariah & 2011 & $2,7 \%$ & $90,5 \%$ & $0,1 \%$ & $90,5 \%$ & $14,7 \%$ \\
\hline & & 2012 & $3,0 \%$ & $95,4 \%$ & $1,1 \%$ & $84,3 \%$ & $11,3 \%$ \\
\hline & & 2013 & $4,0 \%$ & $102,7 \%$ & $1,1 \%$ & $90,1 \%$ & $14,4 \%$ \\
\hline & & 2014 & $4,6 \%$ & $93,9 \%$ & $0,1 \%$ & $96,4 \%$ & $12,8 \%$ \\
\hline & & 2015 & $4,8 \%$ & $84,8 \%$ & $0,7 \%$ & $84,7 \%$ & $13,9 \%$ \\
\hline \multirow[t]{5}{*}{3.} & Bank Syariah Bukopin & 2011 & $1,7 \%$ & $83,6 \%$ & $0,5 \%$ & $93,8 \%$ & $15,2 \%$ \\
\hline & & 2012 & $4,6 \%$ & $92,3 \%$ & $0,6 \%$ & $91,5 \%$ & $12,7 \%$ \\
\hline & & 2013 & $4,3 \%$ & $100,2 \%$ & $0,6 \%$ & $92,2 \%$ & $11,1 \%$ \\
\hline & & 2014 & $4,0 \%$ & $92,8 \%$ & $0,2 \%$ & $96,7 \%$ & $14,8 \%$ \\
\hline & & 2015 & $2,9 \%$ & $90,5 \%$ & $0,7 \%$ & $91,9 \%$ & $16,3 \%$ \\
\hline \multirow[t]{4}{*}{4.} & Bank Syariah Mega & 2011 & $3,0 \%$ & $82,9 \%$ & $1,3 \%$ & $90,8 \%$ & $12,0 \%$ \\
\hline & & 2012 & $2,6 \%$ & $86,1 \%$ & $3,1 \%$ & $80,5 \%$ & $13,5 \%$ \\
\hline & & 2013 & $2,9 \%$ & $92,8 \%$ & $2,3 \%$ & $88,8 \%$ & $12,9 \%$ \\
\hline & & 2014 & $3,8 \%$ & $92,6 \%$ & $0,3 \%$ & $99,6 \%$ & $19,2 \%$ \\
\hline \multirow[t]{5}{*}{5.} & Bank Panin Syariah & 2011 & $0,8 \%$ & $162,9 \%$ & $1,2 \%$ & $74,3 \%$ & $61,9 \%$ \\
\hline & & 2012 & $0,2 \%$ & $124,0 \%$ & $2,2 \%$ & $52,4 \%$ & $32,2 \%$ \\
\hline & & 2013 & $1,0 \%$ & $89,9 \%$ & $0,7 \%$ & $80,8 \%$ & $20,8 \%$ \\
\hline & & 2014 & $0,5 \%$ & $93,3 \%$ & $1,5 \%$ & $75,7 \%$ & $25,6 \%$ \\
\hline & & 2015 & $2,6 \%$ & $94,8 \%$ & $1,1 \%$ & $83,8 \%$ & $20,3 \%$ \\
\hline
\end{tabular}

Pada tabel di atas merupakan hasil dari perhitungan tingkat kesehatan masing-masing rasio pada bank syariah kita dapat melihat pada BNISyariah pada tahun 2012 tingkat rasio NPL mengalami penurunan $1 \%$ namun rasio NPL namun masih berada dalam kondisi sehat. Kemudian pada tahun 2012 rasio BOPO cenderung meningkat dari tahun sebelumnya yaitu dari $87,8 \%$ menjadi $94,6 \%$, dapat disimpulkan bahwa rasio BOPO pada BNI Syariah berada dalam kondisi tidak sehat. Penurunan ini mencerminkan peningkatan efesiensi pengeluaran. Biaya operasional meningkat setiap tahunnya. Untuk rasio ROA BRI Syariah, Bank Syariah Bukopin dan Bank Syariah Mega berada dalam kondisi tidak sehat, karena berada dibawah 
Rohimah Dan Rifki Khoirudin: Komparasi Tingkat Kesehatan Dual Bangking Sistem Antara Divisi Konvensional dan Syariah Di Indonesia

ketentuan batas Bank Indonesia. Aspek likuiditas yang dihitung dengan LDR pada BRI Syariah tahun 2013, Bank Syariah Bukopin tahun 2013, dan Bank Panin Syariah tahun 2011 dan tahun 2011 mengalami kenaikan dibandingkan tahun sebelumnya, maka dapat dikatakan bahwa rasio LDR pada BRI Syariah, Bank Syariah Bukopin, Bank Panin Syariah pada tahun tersebut tidak dalam kondisi sehat. Hal ini dikarenakan adanya peningkatan nilai dana pihak ketiga pada BRI Syariah, Bank Syariah Bukopin dan Bank Panin Syariah sejalan dengan kenaikan jumlah dana pihak ketiga bank juga dalam hal ini menyalurkan dana dalam kepada bentuk pembiayaan terus menunjukan peningkatan. Pada rasio BOPO tahun 2014 masingmasing pada BRI Syariah sebesar 96,4\%, Bank Syariah Bukopin 96,7\%, dan Bank Syariah Mega 99,6\% juga meningkat dibandingkan tahun sebelumnya, artinya tidak dalam keadaan sehat. Hal itu dikarenakan adanya peningkatan dari pendapatan bank dibandingkan tahun sebelumnya. Selebihnya secara keseluruhan berada dalam kriteria sehat.

\section{Hasil Penelitian (uji hipotesis)}

Analisis rasio NPL

Dalam pengujian hipotesis pada rasio NPL antara Bank Konvensional dan Bank Syariah dapat dilihat pada tabel berikut ini:

Tabel 11. Hasil Perhitungan Independent Sample t-test Rasio NPL

\begin{tabular}{llcrrr}
\hline & \multicolumn{1}{c}{ NPL } & F & Sig. & \multicolumn{1}{c}{ T } & Sig. (2-tailed) \\
\hline \multirow{2}{*}{ NPL } & Equal variances assumed & 10,183 &, 003 & $-1,418$ &, 163 \\
& Equal variances not assumed & & & $-1,398$ &, 172 \\
\hline
\end{tabular}

Dari tabel di atas dapat terliat F hitung untuk NPL dengan Equal variances assumed (diasumsikan kedua varians sama) adalah 10,18 dengan probabilitas 0,003. Oleh karena probabilitas data di atas lebih kecil dari 0,05, maka dapat dikatakan bahwa terdapat perbedaan varians pada data perbandingan tingkat kesehatan rasio NPL antara Bank Konvensional dan Bank Syariah.

Bila kedua varian berbeda maka digunakan Equal variances not assumed t-hitung untuk NPL dengan menggunakan Equal variances not assumed adalah -1,39 dengan signifikan sebesar 0,172 . Oleh karena itu nilai sig. $t_{\text {hitung }}>t_{\text {tabel }}(0,172>0,05)$ maka dapat dikatakan bahwa jika dilihat dari rasio NPL maka tingkat kesehatan antara Bank Konvensional dan Bank Syariah tidak terdapat perbedaan yang signifikan.

Analisis rasio LDR. Dalam pengujian hipotesis pada rasio LDR antara Bank Konvensional dan Bank Syariah dapat dilihat pada tabel berikut ini:

Tabel 12. Hasil Perhitungan Independent dan Sample t-test Rasio LDR

\begin{tabular}{llrrrr}
\hline & \multicolumn{1}{c}{ LDR } & F & Sig. & \multicolumn{1}{c}{ t } & Sig. (2-tailed) \\
\hline \multirow{2}{*}{ LDR } & Equal variances assumed &, 017 &, 896 & $-4,220$ &, 000 \\
& Equal variances not assumed & & & $-4,184$ &, 000 \\
\hline
\end{tabular}

Dari tabel di atas dapat terlihat bahwa $\mathrm{F}$ hitung untuk LDR dengan Equal variances assumed (diasumsikan kedua varians sama) adalah 0,017 dengan probabilitas 0,896. Oleh karena itu probabilitas data di atas lebih besar dari 0,05, maka dapat dikatakan bahwa tidak terdapat perbedaan pada data perbandingan tingkat kesehatan rasio LDR antara Bank Konvensional dengan Bank Syariah.

Bila kedua varians sama maka digunakan Equal Variances Assumed adalah -4,220 dengan signifikan sebesar 0,000 . Oleh karena itu nilai sig. $t_{\text {hitung }}<t_{\text {tabel }}(0,000<0,05)$, maka 
dapat dikatakan bahwa jika dilihat dari rasio LDR maka tingkat kesehatan antar Bank Konvensional dan Bank Syariah terdapat perbedaan yang signifikan.

Hal ini karena adanya peningkatan pemberian jumlah kredit ditiap tahunnya pada bank konvensional maupun bank syariah, walaupun terjadi penurunan pada beberapa tahun namun penurunan tesebut tidak terlalu besar. Menurut Laporan Tahunan Perbankan tahun 2015 penyaluran pembiayaan perbankan syariah tahun 2015 mengalami peningkatan yaitu sebesar Rp213 triliun dari tahun sebelimnya yaitu sebesar Rp199,3 triliun. Selain itu DPK perbankan syariah juga tumbuh sebesar $6,11 \%$ dari deposito, tabungan, dan giro masing-masing sebesar $61,13 \%, 29,70 \%, 9,17 \%$.

\section{Analisis rasio ROA}

Dalam pengujian hipotesis pada rasio ROA antara Bank Konvensional dan Bank Syariah dapat dilihat pada tabel berikut ini:

Tabel 13. Hasil Perhitungan Independent dan Sample t-test Rasio ROA

\begin{tabular}{lllrrr}
\hline & \multicolumn{1}{c}{ ROA } & F & Sig. & T & Sig. (2-tailed) \\
\hline \multirow{2}{*}{ ROA } & Equal variances assumed & 4,912 &, 032 & 4,994 &, 000 \\
& Equal variances not assumed & & & 5,035 &, 000 \\
\hline
\end{tabular}

Dari tabel di atas dapat terlihat bahwa $\mathrm{F}$ hitung untuk ROA dengan Equal variances assumed (diasumsikan kedua varians sama) adalah 4,912 dengan probabilitas 0,032. Oleh karena itu probabilitas data di atas lebih kecil dari 0,05, maka dapat dikatakan bahwa terdapat perbedaan pada data perbandingan tingkat kesehatan rasio ROA antara Bank Konvensional dengan Bank Syariah.

Bila kedua varians berbeda maka digunakan Equal Variances not Assumed adalah 5,035 dengan signifikan sebesar 0,000. Oleh karena itu nilai sig. $t_{\text {hitung }}<t_{\text {tabel }}(0,000<0,05)$, maka dapat dikatakan bahwa jika dilihat dari rasio ROA maka tingkat kesehatan antar Bank Konvensional dan Bank Syariah terdapat perbedaan yang signifikan. Jika dilihat dari koefisien berdasarkan uji t maka antara inflasi sebesar 5.6360 dan suku bunga sebesar 6.8640, dari nilai tersebut terlihat yang paling dominan dalam pembentukan ROA adalah inflasi. Inflasi mempengaruhi ROA karena dengan adanya kenaikan inflasi maka diikuti oleh kenaikan suku bunga SBI dan suku bunga kredit. . Karena saat inflasi naik minat masyarakat untuk menabung, berinvestasi dan berproduksi menjadi berkurang. Masyarakat akan mempergunakan hartanya untuk mencukupi biaya pengeluaran akibat naiknya harga-harga barang sehingga akan mempengaruhi profitabilitas bank. Dan ketika inflasi turun yang diikuti dngan turunnya suku bunga SBI dan juga suku bunga kredit, masyarakat akan kembali menabung, berinvestasi, dan juga berproduksi sehingga DPK bank dapat meningkat.

Peningkatan DPK bank sangat berpengaruh pada pemberian kredit pada masyarakat. Dengan DPK yang tinggi bank juga dapat memberikan jumlah kredit yang banyak pada masyarakat, sehingga bank dapat memperoleh profitnya dari bunga kredit yang dibebankan pada masyarakat yang mengambil kredit pada bank tersebut. Berikut adalah data inflasi dan suku bunga periode 2011-2015. 
Rohimah Dan Rifki Khoirudin: Komparasi Tingkat Kesehatan Dual Bangking Sistem Antara Divisi Konvensional dan Syariah Di Indonesia

Tabel 14. Inflasi dan Suku Bunga

\begin{tabular}{cccc}
\hline No & Tahun & Inflasi & Suku Bunga \\
\hline 1. & 2011 & $3,79 \%$ & $6,00 \%$ \\
2. & 2012 & $4,30 \%$ & $5,57 \%$ \\
3. & 2013 & $8,38 \%$ & $7,50 \%$ \\
4. & 2014 & $8,36 \%$ & $7,75 \%$ \\
5. & 2015 & $3,35 \%$ & $7,50 \%$ \\
\hline
\end{tabular}

Tabel 15. Hasil Mean dan Standar Deviation

\begin{tabular}{ccccc}
\hline \multicolumn{2}{c}{ KELOMPOK } & N & Mean & Std. Deviation \\
\hline \multirow{2}{*}{ ROA } & INFLASI & 5 & 5.6360 & 2.51834 \\
& SUKUBUNGA & 5 & 6.8640 & 1.00186 \\
\hline
\end{tabular}

\section{Analisis Rasio BOPO}

Dalam pengujian hipotesis pada rasio BOPO antara Bank Konvensional dan Bank Syariah dapat dilihat pada tabel berikut ini:

Tabel 16. Hasil Perhitungan Independent dan Sample t-test Rasio BOPO

\begin{tabular}{llcrrr}
\hline \multicolumn{1}{c}{ BOPO } & F & Sig. & T & Sig. (2-tailed) \\
\hline \multirow{2}{*}{ BOPO } & Equal variances assumed & 4,692 &, 035 & $-4,613$ &, 000 \\
& Equal variances not assumed & & & $-4,633$ &, 000 \\
\hline
\end{tabular}

Dari tabel di atas dapat terlihat bahwa F hitung untuk BOPO dengan Equal variances assumed (diasumsikan kedua varians sama) adalah 4,692 dengan probabilitas 0,035. Oleh karena itu probabilitas data di atas lebih kecil dari 0,05, maka dapat dikatakan bahwa terdapat perbedaan pada data perbandingan tingkat kesehatan rasio BOPO antara Bank Konvensional dengan Bank Syariah.

Bila kedua varians berbeda maka digunakan Equal Variances not Assumed adalah 4,633 dengan signifikan sebesar 0,000. Oleh karena itu nilai sig. $t_{\text {hitung }}<t_{\text {tabel }}(0,000<0,05)$, maka dapat dikatakan bahwa jika dilihat dari rasio BOPO maka tingkat kesehatan antar Bank Konvensional dan Bank Syariah terdapat perbedaan yang signifikan. Adanya perbedaan yang tidak signifikan pada rasio BOPO dipengaruhi oleh nilai NPM yang tiap tahunnya menurun dikerenakan adanya inflasi yang naik pada tahun 2013 dan 2014 sehingga mempengaruhi investasi dan akan mempengaruhi pendapatan operasional bank.

Tabel 17. Hasil Perhitungan Rasio NPM pada Bank Konvensional (dalam hitungan persen)

\begin{tabular}{clrrrrr}
\hline No. & Nama Bank & $\mathbf{2 0 1 1}$ & $\mathbf{2 0 1 2}$ & $\mathbf{2 0 1 3}$ & $\mathbf{2 0 1 4}$ & $\mathbf{2 0 1 5}$ \\
\hline 1. & BNI & 80,19 & 81,57 & 80,74 & 81,14 & 80,09 \\
2. & BRI & 85,80 & 82,39 & 81,73 & 85,58 & 83,28 \\
3. & Bank Bukopin & 79,54 & 79,11 & 79,50 & 77,17 & 82,23 \\
4. & Bank Mega & 95,82 & 89,56 & 88,33 & 88,34 & 89,57 \\
5. & Bank Panin & 77,31 & 76,81 & 76,61 & 73,41 & 64,60 \\
\hline \multicolumn{2}{r}{ Jumlah } & 415,45 & 407,22 & 406,91 & 405,64 & 339,81 \\
\hline
\end{tabular}


Tabel 18. Hasil Perhitungan Rasio NPM pada Bank Syariah (dalam hitungan persen)

\begin{tabular}{clrrrrr}
\hline No. & Nama Bank & $\mathbf{2 0 1 1}$ & $\mathbf{2 0 1 2}$ & $\mathbf{2 0 1 3}$ & $\mathbf{2 0 1 4}$ & $\mathbf{2 0 1 5}$ \\
\hline 1. & BNI Syariah & 69,08 & 72,15 & 61,27 & 73,43 & 79,64 \\
2. & BRI Syariah & 77,33 & 77,75 & 72,09 & 57,84 & 77,14 \\
3. & Bank Syariah Bukopin & 81,03 & 66,12 & 63,17 & 52,69 & 66,08 \\
4. & Bank Syariah Mega & 71,16 & 72,99 & 80,15 & 75,09 & \\
5. & Bank Panin Syariah & 75,06 & 75,04 & 73,37 & 72,75 & 68,75 \\
\hline & Jumlah & 737,66 & 364,05 & 350,05 & 331,80 & 291,25 \\
\hline
\end{tabular}

\section{Analisis rasio CAR}

Dalam pengujian hipotesis pada rasio CAR antara Bank Konvensional dan Bank Syariah dapat dilihat pada tabel berikut ini:

Tabel 19. Hasil Perhitungan Independent dan Sample t-test Rasio CAR

\begin{tabular}{llrrrr}
\hline & & F & Sig. & T & Sig. (2-tailed) \\
\hline \multirow{2}{*}{ CAR } & Equal variances assumed & 5,588 &, 022 &,- 930 &, 357 \\
& Equal variances not assumed & & &,- 913 &, 370 \\
\hline
\end{tabular}

Dari tabel di atas dapat terlihat bahwa $\mathrm{F}$ hitung untuk CAR dengan Equal variances assumed (diasumsikan kedua varians sama) adalah 5,588 dengan probabilitas 0,022. Oleh karena itu probabilitas data di atas lebih kecil dari 0,05, maka dapat dikatakan bahwa terdapat perbedaan pada data perbandingan tingkat kesehatan rasio CAR antara Bank Konvensional dengan Bank Syariah.

\section{SIMPULAN}

Berdasarkan perhitungan yang telah dilakukan dalam penelitian ini pada masing-masing rasio yaitu NPL, LDR, ROA, BOPO dan CAR pada Bank Konvensional berada dalam kriteria sehat. Pada Bank Syariah LDR yang dimiliki pada BRI Syariah tahun 2013, Bank Syariah Bukopin tahun 2013 dan Bank Panin Syariah pada tahun 2011 dan 2012 berada dalam kondisi tidak sehat, hal ini dikarenakan adanya peningkatan nilai dana pihak ketiga dengan kenaikan jumlah pembiayaan yang diberikan oleh bank. Sedangkan untuk rasio ROA kondisi bank yang tidak sehat dimiliki oleh bank BRISyariah pada tahun 2011 dan 2014, Bank Syariah Bukopin tahun 2014, dan Bank Syariah Mega tahun 2014. Pada BNISyariah tahun 2012, BRISyariah tahun 2014, Bank Syariah Bukopin tahun 2014 serta Bank Syariah Mega tahun 2014 berada pada rasio BOPO yang tidak sehat, hal ini dikarenakan karena adanya peningkatan pengeluaran. Dan untuk rasio CAR pada bank Syariah berada dalam kondisi sehat.

Pada penelitian kali ini hasil dari uji statistik independent sample t-test pada rasio NPL dan CAR tidak terdapat perbedaan yang signifikan. Sedangkan pada rasio LDR, ROA, dan BOPO terdapat perbedaan yang signifikan.

\section{Saran}

Tingkat kesehatan Bank Konvensioal lebih baik dibandingkan dengan tingkat kesehatan pada Bank Syariah. Namun bagi Bank Konvensional harus mempertahankan bahkan meningkatkan lagi kinerja keuangannya agar teteap berada dalam kriteria sehat seperti yang telah ditentukan oleh Bank Indonesia.

Bagi Bank Syariah 
Rohimah Dan Rifki Khoirudin: Komparasi Tingkat Kesehatan Dual Bangking Sistem Antara Divisi Konvensional dan Syariah Di Indonesia

Karena secara rata-rata Bank Syariah memiliki tingkat kesehatan yang rendah dibanding tingkat kesehatan pada Bank Konvensional. Maka bank Syariah sebaiknya meningkatkan kinerja keuangannya sehingga dapat bersaing dengan Bank Konvensional, dengan cara pengelolaan manajemen yang baik agar meningkatnya jumlah laba yang diperoleh dan terdistribusikannya pembiayaan yang tepat sasaran. Terutama untuk beberapa rasio pada Bank Syariah.

\section{DAFTAR PUSTAKA}

Bank Indonesia. 2011. Surat Edaran Bank Indonesia No.13/ 24 /DPNP Jakarta, 25 Oktober 2011. www.bi.go.id. (di akses tanggal 26 Oktober 2016).

Bank Indonesia. 2011. Data Inflasi Jakarta, 1 Januari 2011. www.bi.go.id. (di akses tanggal 8 Mei 2017).

Bank Indonesia. 2011. Data BI Rate Jakarta, 1 Januari 2011. www.bi.go.id. (di akses tanggal 8 Mei 2017).

Bank Indonesia. 2011. Suku Bunga Dasar Kredit Jakarta, 1 Januari 2011. www.bi.go.id. (di akses tanggal 8 Mei 2017).

Bank Indonesia. 2012. Kodifikasi Peraturan Bank Indonesia tentang Penilaian Tingkat Kesehatan Bank. Pusat Riset dan Edukasi Bank Sentral.

Bank Bukopin. Laporan Keuangan Bank Negara Bukopin. Jakarta: Bank Bukopin.

Bank Mega. 2011,2012,2013,2014. Laporan Keuangan Bank Mega. Jakarta: Bank Mega.

Bank Negara Indonesia. Laporan Keuangan Bank Negara Indonesia. Jakarta: Bank Negara Indonesia.

Bank Negara Indonesia Syariah. 2011,2012,2013,2014,2015. Laporan Keuangan Bank Negara Indonesia Syariah. Jakarta: Bank Negara Indonesia Syariah.

Bank Panin. Laporan Keuangan Bank Panin. Jakarta: Bank Panin.

Bank Panin Syariah. Laporan Keuangan Bank Panin Syariah. Jakarta: Bank Panin Syariah.

Bank Rakyat Indonesia. 2011,2012,2013,2014,2015. Laporan Keuangan Bank Negara Rakyat Indonesia. Jakarta: Bank Rakyat Indonesia.

Bank Rakyat Indonesia Syariah. 2011,2012,2013,2014,2015. Laporan Keuangan Bank Negara Rakyat Indonesia Syariah. Jakarta: Bank Rakyat Indonesia.

Bank Syariah Bukopin. 2011,2012,2013,2014,2015. Laporan Keuangan Bank Negara Syariah Bukopin. Jakarta: Bank Syariah Bukopin.

Bank Syariah Mega. 2011,2012,2013,2014. Laporan Keuangan Bank Syariah Mega. Jakarta: Bank Syariah Mega.

Djarwanto, PS; Subagyo, P. 2002. Statistik Induktif. Yogyakarta: BPEE.

Hasibuan, Malayu S.P. 2006. Dasar-Dasar Perbankan. PT Bumi Aksara. Jakarta.

Hidayatika, Siti Ayu Dkk. 2016. Analisis Perbedaan Tingkat Kesehatan Bank Konvensional Dengan Menggunakan Metode RGEC (Studi Pada Bank Konvensional yang Listing di BEI 2011-2014), Universitas Islam Negeri Maulana Malik Ibrahim Malang.

Kasmir , S.E. MM. 2014. Manajemen Perbankan. Jakarta: PT.Raja Grafindo Persada.

Pemerintah Indonesia. Undang-Undang Nomor. 7 Tahun 1992 tentang Perbankan.

Pemerintah Indonesia. Undang-Undang Nomor. 10 Tahun 1998 dan Nomor. 19 tahun 1998 tentang perbankan.

Sinangun, Muchdarsyah. 1993. Manajemen Dana Bank. Edisi ke-2, Cetakan ke-2. Jakarta : PT. Bumi Aksara

Widyaningrum, Hening Asih Dkk. 2014. Analisis Tingkat Kesehatan Bank Dengan Menggunakan Metode Risk-Based Bank Rating (RBBB) (Studi Pada Bank yang Terdaftar di Bursa Efek Indonesia IHSG Sub Sektor Perbankan Tahun 2012), Jurnal Administrasi Bisnis. 